2. The optimum $\mathrm{pH}$ for the decomposition of phenolphthalein glucuronide by the enzyme was $6 \cdot 1$.

3. Irreversible inactivation of the enzyme occurred on incubation for a short period at a $\mathrm{pH}$ lower than 6 or higher than 7 .

4. On the assumption that the rate of liberation of phenolphthalein from the glucuronide was governed by a single reaction a value of $3.05 \times 10^{-5} \mathrm{M}$ was obtained for the dissociation constant of the active enzyme-substrate complex. Excess substrate caused pronounced inhibition of the enzyme. The inactive complex contained two substrate molecules per active enzyme centre, and the second dissociation constant was $0.0126 \mathrm{M}$.

5. Saccharate caused only slight inhibition of the enzyme in comparison with its effect on animal $\beta$-glucuronidase.

The authors wish to express their gratitude to $\operatorname{Dr} \mathbf{A} . \mathbf{E}$ Oxford for assistance and advice in microbiological aspects of this work, and to Dr A. T. Phillipson for the supply of sheep with rumen fistulae.

\title{
REFERENCES
}

Boswell, J. G. (1941). New Phytol. 40, 20.

Buehler, H. J., Katzman, P. A. \& Doisy, E. A. (1949). Fed. Proc. 8, 189.

Chibnall, A. C., Rees, M. W. \& Williams, E. F. (1943). Biochem. J. 37, 354.

Conway, E. J. (1947). Micro-Diffusion Analysis and Volumetric Error, 2nd ed. London: Crosby Lockwood.

Elsden, S. R. \& Phillipson, A. T. (1948). Ann. Rev. Biochem. 17, 705 .

Fåhræus, G. (1947). Symb. bot. upsaliens. 9, no. 2.

Hungate, R. E. (1950). Bact. Rev. 14, 1.

Karunairatnam, M. C. \& Levvy, G. A. (1949). Biochem. J. 44, 599 .
Lineweaver, H. \& Burk, D. (1934). J. Amer. chem. Soc. 56, 658.

Markham, R. (1942). Biochem. J. 36, 790.

Mickle, H. (1948). J. R. micr. Soc. 68, 10.

Moir, R. J. \& Marsh, C. A. (1950). Unpublished observations.

Norman, A. G. (1937). The Biochemistry of Cellulose, the Polyuronides, Lignin etc. Oxford: University Press.

Norman, A. G. \& Fuller, W. H. (1942). Advanc. Enzymol. 2, 239.

Quin, J. I. (1943). Ondersteeport J. vet. Sci. 18, 91. '

Talalay, P., Fishman, W. H. \& Huggins,-C. (1946). J. biol. Chem. 166, 757.

\section{The Chromatographic Fractionation of Ribonuclease}

\author{
By A. J. P. MARTIN AND R. R. PORTER \\ National Institute for Medical Research, Mill Hill, London, N.W. 7
}

\section{(Received 18 November 1950)}

During a study of the partial hydrolysis of ribonuclease (Porter, 1950), it became necessary to separate enzymically active products from the original enzyme and other substances. In some cases the degradation appeared to be slight and little change in solubility or other physical properties seemed to have occurred. Conventional methods of protein purification, such as precipitation with salts or organic solvents proved unsuccessful, and attention was therefore turned to partition between two liquid phases. The system ammonium sulphatewater-ethanol was used very successfully by Herbert \& Pinsent (1948) in the purification of bacterial catalase. In some preliminary experiments with haemoglobin (Martin, 1949), the system ammonium sulphate-water-ethylene glycol monoethyl ether ('cellosolve') was found to be less likely than most to cause denaturation. This system was therefore chosen for investigation, though ribonuclease is so stable a protein that many systems may well be satisfactory. In one case, however, the ratio of the partition coefficient of ribonuclease to that of the aggregate of its hydrolysis products was about 3:2. This system could yield a satisfactory separation only with the aid of a counter-current extraction train of very high efficiency, or of a partition chromatogram. The latter was chosen, using kieselguhr to support the stationary phase, since cellulose, starch or precipitated silica would have probably too fine a structure to admit a protein molecule.

These columns proved very successful, and revealed the presence of two enzymically active components in the original crystalline ribonuclease.

\section{MATERIALS}

Ribonuclease was prepared from ox pancreas by the method of Kunitz (1940) and also by the modified procedure of McDonald (1948). It was recrystallized several times and was homogeneous in the Tiselius electrophoresis apparatus at $\mathrm{pH} \mathbf{7 \cdot 4}$ and $8 \cdot 5$.

The kieselguhr was Hyflo Supercel obtained from the Johns Manville Co. Ltd., London. It was used without pretreatment. 


\section{METHODS}

Ribonuclease assay was carried out as described by Kunitz (1940). The activity of the enzyme preparations is expressed in the nuclease units (N.U.) of Kunitz. One N.U. is the activity which gives rise under standard conditions to the formation of $1 \times 10^{-3} \mathrm{mg}$. of soluble phosphorus per $\mathrm{ml}$. of digestion mixture in a range of concentrations of enzymes where the amount of soluble phosphorus formed is proportional to the concentration of enzyme used.

The relative protein concentration of the concentration of the eluates was followed by measuring the absorption at $275 \mathrm{~m} \mu$. in a Beckman photoelectric absorptiometer.

\section{Choice of solvent mixture and preparation of the chromatogram}

The phase diagram of the system $\left(\mathrm{NH}_{4}\right)_{2} \mathrm{SO}_{4}$-watercellosolve (Fig. 1) was determined by titrating a saturated solution of $\left(\mathrm{NH}_{4}\right)_{2} \mathrm{SO}_{4}$ in water with cellosolve until a faint opalescence showed the presence of two phases. Water was then added and the titration continued. The tie lines were determined from the $\left(\mathrm{NH}_{4}\right)_{2} \mathrm{SO}_{4}$ content of both phases of a number of arbitrary mixtures.

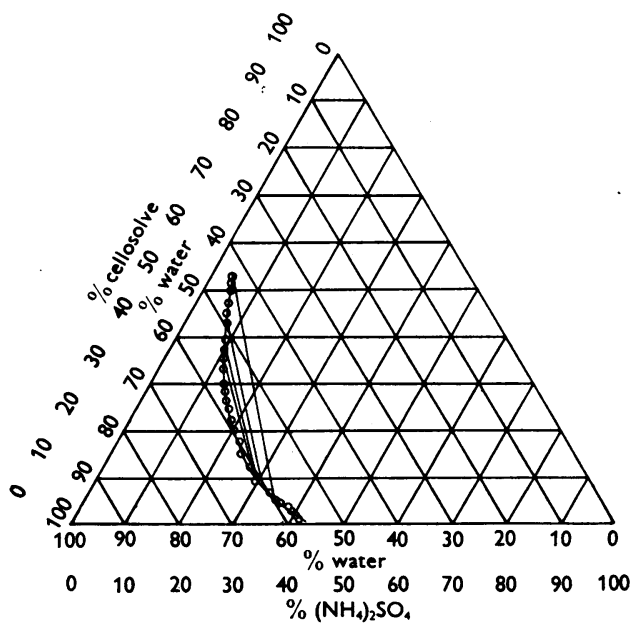

Fig. 1. Phase diagram of the system ammonium sulphatewater-ethylene glycol monoethyl ether at $20^{\circ}$.

Using the phase diagram a number of mixtures were chosen and tested. The choice was restricted by the limited solubility of the enzyme in aqueous phases having a high salt content, since the assay was disturbed by excess of $\left(\mathrm{NH}_{4}\right)_{2} \mathrm{SO}_{4}$ and the sample had to be diluted considerably before test. Three mixtures used successfully had the following composition (by weight):

(a) Water, $47 \%$; $\left(\mathrm{NH}_{4}\right)_{2} \mathrm{SO}_{4}, 16.5 \%$; cellosolve $36.5 \%$.

(b) Water, $55 \%$; $\left(\mathrm{NH}_{4}\right)_{2} \mathrm{SO}_{4}, 15 \%$; cellosolve, $30 \%$.

(c) Water, $56 \%$; $\left(\mathrm{NH}_{4}\right)_{2} \mathrm{SO}_{4}, 20 \%$; cellosolve, $24 \%$.

Of these mixtures (c) was perhaps the most useful and has been employed in much of this work.
The partition coefficients of the crystalline enzyme in two of the mixtures were $(a) 10,(b) 6$ in favour of the upper (cellosolve) layer. The organic phase had, therefore, to be the stationary one, and the aqueous the mobile phase. For reasons not fully understood the kieselguhr was wetted preferentially by the organic phase, and it was therefore unnecessary to use silane-treated silica (Howard \& Martin, 1950). Indeed it has not as yet proved possible to produce columns with the aqueous phase stationary.

The column is prepared by mixing the kieselguhr with half its weight of the organic phase, making this into a slurry with excess of the aqueous phase and pouring into the chromatogram tube. For most of the work columns containing $6 \mathrm{~g}$. of kieselguhr in a tube $1.2 \mathrm{~cm}$. internal diameter were used. Such a column can conveniently handle 1-5 mg. ribonuclease dissolved in $2 \mathrm{ml}$. of aqueous phase.

\section{RESULTS}

The elution of the enzyme was followed both by estimating the absorption at $275 \mathrm{~m} \mu$. and by estimating the activity. In Fig. 2 it can be seen that these follow each other closely, but that two distinct peaks are visible instead of the single peak expected.

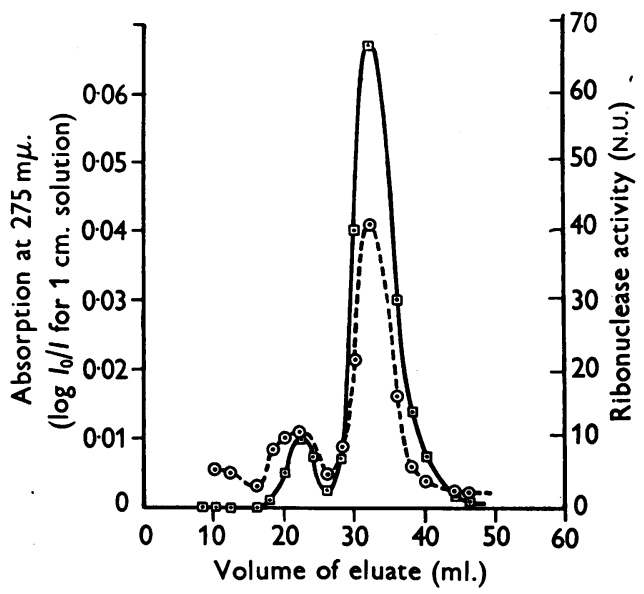

Fig. 2. Chromatogram of ribonuclease. System: $20 \mathrm{~g}$. $\left(\mathrm{NH}_{4}\right)_{2} \mathrm{SO}_{4}, 24 \mathrm{~g}$. cellosolve, $56 \mathrm{~g}$. water; $6 \mathrm{~g}$. silica column. -, enzymic activity; $\ldots$. . , absorption at $275 \mathrm{~m} \mu$.

In Fig. 3 are shown the elution curves of the same enzymic material using different solvent mixtures. It will be observed that the relative proportion of the two components as judged from the area beneath the peaks remains approximately constant, although the degree of separation varies considerably.

As it therefore appeared that the enzyme existed in two forms it was necessary to decide whether either could be an artifact of the column or of the method of preparation of the enzyme from the pancreas. Material concentrated from the eluate containing either peak could be re-run upon the chromatogram to give a clean single peak, showing that no alteration was occurring here. 
In the preparation there are two apparent ways in which degradation might occur. First, in McDonald's modification of the Kunitz method of preparation, proteolytic activity, always present as contaminant in the older method, is destroyed by heating at $100^{\circ}$ for $10 \mathrm{~min}$. It was possible that some hydrolysis of

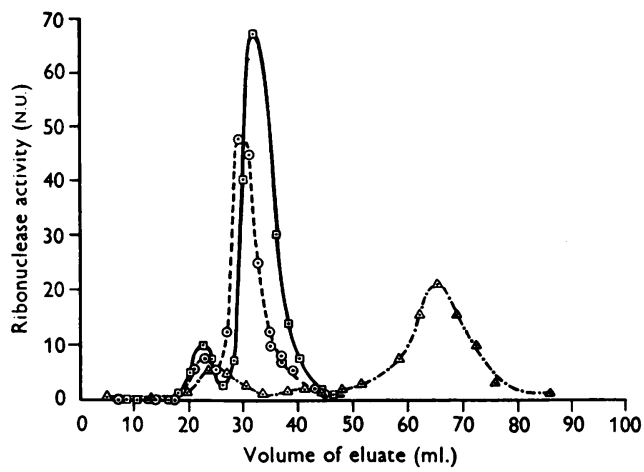

Fig. 3. Chromatograms of ribonuclease. $\odot---\odot$, system: $15 \mathrm{~g}$. $\left(\mathrm{NH}_{4}\right)_{2} \mathrm{SO}_{4}, 30 \mathrm{~g}$. cellosolve, $55 \mathrm{~g}$. water; $6 \mathrm{~g}$. silica column; $\square-\square$, system : $20 \mathrm{~g}$. $\left(\mathrm{NH}_{4}\right)_{2} \mathrm{SO}_{4}, 24$ g. cellosolve, 56 g. water; 6 g. silica column; $\triangle-\cdot-\cdot-\Delta$, system: $16 \cdot 5 \mathrm{~g}$. $\left(\mathrm{NH}_{4}\right)_{2} \mathrm{SO}_{4}, 36.5 \mathrm{~g}$. cellosolve, $47 \mathrm{~g}$. water; $3 \mathrm{~g}$. silica column.

amide groups or some other type of degradation might occur. Ribonuclease was therefore prepared omitting this step; nevertheless, two peaks were still present in the same ratio. As further confirmation, the main peak was collected from a chromatogram, heated to $100^{\circ}$ for $15 \mathrm{~min}$. and again run. Once more only a single peak appeared and in the same position as before heating.

The other probable explanation of the appearance of the second peak was that the powerful proteolytic enzymes of the pancreas caused some hydrolysis of the ribonuclease during the initial extraction. The method of preparation is a series of ammonium sulphate precipitations of a dilute sulphuric acid extract of the minced gland. Most of the work was carried out in a cold room until final crystallization, but as it continued over 5 or 6 days, proteolytic action could not be ruled out. An alternative method of preparation was therefore devised. The pancreas was taken immediately after slaughter and covered with solid carbon dioxide. The frozen glands were allowed to thaw sufficiently to be homogenized with 2 vol. $0.5 \mathrm{M}(8 \%, w / v)$ trichloroacetic acid in a Waring blender. This extraction was repeated and trichloroacetic acid was added to the combined filtrates to give a final concentration of $10 \%(w / v)$. The precipitate, which was readily soluble in water, contained most of the original ribonuclease activity. After dialysis against water in the cold it was freezedried. It seems unlikely that during this method of preparation any proteolysis could have occurred and from the activity:nitrogen ratio the material appeared to be about 30-50\% pure. Fig. 4 shows the chromatogram obtained with this material and it can be seen that again the smaller component appears in the same position, though perhaps in a larger relative amount.

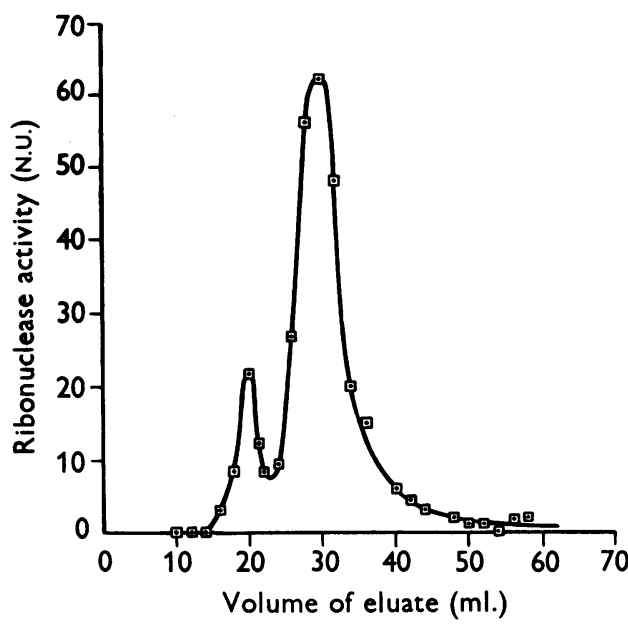

Fig. 4. Chromatogram of ribonuclease prepared by the trichloroacetic acid method. System: $20 \mathrm{~g}$. $\left(\mathrm{NH}_{4}\right)_{2} \mathrm{SO}_{4}$, 20 g. cellosolve, 56 g. water; 6 g. silica column.

\section{DISCUSSION}

Comparison of the partition coefficient derived from the rate of movement of the bands (Martin \& Synge, 1941) and that measured directly shows that the columns are not behaving simply as partition chromategrams. The bands move much more slowly than expected. (Expected $R=(a) 0.28,(b) 0.45$. Found $R=(a) 0.08,(b) 0.30$.) Since in the absence of the stationary phase the kieselguhr shows no adsorption, adsorption must be occurring in the interface between the two liquid phases. As might be expected, the discrepancy is greater, and hence adsorption also, with solvents of high salt content.

Perhaps related to this adsorption into the interface is the surprising efficiency of the separation, which is indeed about what would be expected with small molecules on the same columns, and this is in spite of the fact that the rate of flow of the liquid was certainly no slower than normal. If the bulk of the proteins were not in the interface, its low diffusion constant should cause low separation efficiency unless the flow rate was extremely small.

From the evidence presented it seems reasonable to conclude that ribonuclease exists in beef pancreas in two distinct forms; recrystallization failed to eliminate the smaller component, though if repeated often enough this might be possible. It has been shown previously that proteins with the same 
specific biological activity when isolated from different species may differ chemically. The haemo. globins are an example of this (Porter \& Sanger, 1948), and it is clear that some variation in structure may occur in such a series of compounds without the specific action being greatly modified. From solubility studies, Desreux \& Herriott (1939) postulated the existence of at least two components in swine pepsin, both of which possess enzymic activity. It is probable that the duality of ox ribonuclease is a similar phenomenon. As a similar composition was found for a number of preparations made from small numbers of pancreases obtained over 12 months from different slaughter houses, it would seem that the two forms exist together rather than that individual animals have wholly one or the other type. The structural differences which alter the chromatographic behaviour have not yet been investigated and may well be subtle enough to escape detection by the technique at present available.
From the aspect of protein structure these results would appear to give support to the idea of the existence of families of nearly identical proteins (cf. Synge, 1950).

\section{SUMMARY}

1. A partition chromatogram using the two liquid phases produced by mixtures of ammonium sulphate, ethylene glycol monoethyl ether ('cellosolve') and water has been devised with kieselguhr used as the inert support.

2. On such chromatograms crystalline ribonuclease gives without difficulty zones having convenient rates and symmetrical form. It was found to contain two enzymically active components in the approximate ratio $10: 1$.

3. Evidence is presented which suggests that both forms pre-exist in ox pancreas.

We wish to thank Mrs A. Dovey for her electrophoretic examination of ribonuclease.

\title{
REFERENCES
}

Desreux, V. \& Herriott, R. M. (1939). Nature, Lond., 144, 287.

Herbert, D. \& Pinsent, A. J. (1948). Biochem. J. 43, 193.

Howard, G. A. \& Martin, A. J. P. (1950). Biochem. J. 46, 532.

Kunitz, M. (1940). J. gen. Physiol. $24,15$.

MoDonald, M. R. (1948). J. gen. Physiol. 32, 39.
Martin, A. J. P. (1949). Unpublished observations.

Martin, A. J. P. \& Synge, R. L. M. (1941). Biochem. J. 35, 1558.

Porter, R. R. (1950). Unpublished observations.

Porter, R. R. \& Sanger, F. (1948). Biochem. J. 42, 287.

Synge, R. L. M. (1950). Cold Spr. Harb. Symp. quant. Biol. 14, 191.

\section{Inhibition of Alkaline Phosphatase by Oestradiol Phosphates}

\author{
By B. ALDMAN, E. DICZFALUSY, B. HÖGBERG AND T. ROSENBERG \\ The Department of Women's Diseases, Karolinska Sjukhuset, Stockholm; The Research Department, \\ $A B$ Leo, Hälsingborg, and The Biochemical Department, Nordisk Insulinlaboratorium, Copenhagen
}

(Received 18 September 1950)

In a preliminary report Aldman, Diczfalusy \& Rosenberg (1948) have shown that kidney alkaline phosphatase is inhibited by some phosphoric acid esters of the oestrogenic steroids. In this paper more detailed data are presented as to the specificity, reversibility and mode of inhibition.

\section{MATERIALS AND METHODS}

Enzyme. The enzyme was prepared, as previously, from the kidneys of young rabbits, using with slight modifications the method described by van Thoai, Roche \& Sartori (1944). In the course of repeated fractionations it was found that the enzymic activity of the crystalline material decreased simultaneously with increasing activity of the mother liquor, confirming thus the results of Abul-Fadl, King, Roche \& van Thoai (1949), according to which the crystals consist of inorganic material with enzyme adsorbed on it. In some experiments electrophoretically purified enzyme has been used.

Substrates. The following substrates have been used: phenyl phosphate, $\beta$-glycerophosphate and glucose-6phosphate (the last-named compound was kindly supplied by Dr O. Lindberg, Wenner-Gren Institute, Stockholm).

Analytical methods. Phenol was determined with Folin's reagent as described by Buch \& Buch (1939), inorganic phosphate according to Lowry \& Lopez (1946), and in some instances with a modified Martin \& Doty (1949) method. The measurements were carried out in a Beckman spectrophotometer.

Conditions of enzyme experiments. Enzyme activity determinations were carried out within the $\mathrm{pH}$ range $7 \cdot 0-11 \cdot 0$, using a $0.04 \mathrm{M}$-borate-carbonate-acetate buffer. Reaction volume, generally 2.5 or $5.0 \mathrm{ml}$.; incubation time, 10 or $16 \mathrm{~min}$. at $37^{\circ}$. Enzyme concentration, $1 \cdot 0 \mu \mathrm{g}$. of protein $/ \mathrm{ml}$., or less. 